\title{
Book Review: Ogbulu, O.M. 2012, All-Asset Market Portfolio And The Risk-Return Behavior of Assets: Evidence From The Nigerian Capital Market: LAP Lambert Academic Publishing, Saarbrucken, Germany, ISBN 978-3-659-25809-1
}

\author{
Hamilton O. Isu. \\ Professor of Finance, Abia State University \\ Uturu, Nigeria and one-time 'Bank and Finance' analyst at the Federal Reserve Bank of New York, USA \\ E-mail: hrhogbulu@yahoo.com
}

Received: 07-04- 2013

doi:10.7575/aiac.ijfas.v.1n.1p.34
Accepted: 25-04- 2013

Published: 30-04- 2013

URL: http://dx.doi.org/10.7575/aiac.ijfas.v.2n.1p.34

\begin{abstract}
The book "All-Asset Market Portfolio and The Risk-Return Behaviour of Assets: Evidence from The Nigerian Capital Market" by Dr. Ogbulu, O.M. represents an engaging and stimulating re-examination of the capital asset pricing paradigm. The focus of the book, which covers about 164 pages and comprises five chapters, is to demonstrate that the concept of the market portfolio which is central to the development and application of the Capital Asset Pricing Model (CAPM) has for so long been misconstrued with respect to its true meaning by various scholars and practitioners alike in portfolio and security analysis.
\end{abstract}

In a concise and lucid language, the author has been able to show that within a given and precise capital market, it is very feasible and practicable to construct an all-inclusive and market-value weighted market portfolio as required by the CAPM, which the author has rightly labeled "All-Asset Market Portfolio." As stated by the author, such an All-Asset market portfolio is very important if unbiased and reliable riskadjusted expected rates of return are to be generated within the CAPM framework. This is true because as argued by the author in chapter two of the book, we need reliable estimates of market parameters, namely-market returns and the standard deviation of market returns- to be able to obtain reliable estimates of the expected rates of returns on capital assets using the CAPM methodology and as observed by the author, this has hardly been the case in practice as well as in empirical tests of the validity of the CAPM.

Instead, many scholars and practitioners have been contented working with various "proxies" of the market portfolio depending on convenience and perhaps availability of such proxies. This attitude, according to the author, can hardly be productive of results and is capable of leading to unreliable and inconclusive empirical results in studies conducted to test the empirical validity of the CAPM.

This is the central problem which the author set out to address in this compact textbook and having perused the entire book one is of the firm opinion that Dr. Ogbulu has acquitted himself very well in treating the contentions in the book. This book therefore, represents a very bold and radical call for a reexamination of the various studies and researches earlier conducted to test the validity of the CAPM. In other words, the application of an All-Asset market portfolio as the true and proper market portfolio in such studies as against a "sub-optimal" proxy market portfolio like the NYSE Composite index, the S\&P 500 stock index, the Dow Jones Industrial Average or the NSE All-Share index etc may well lead to entirely different results and conclusions. For as stated by Roll (1977), the CAPM is untestable unless the true and exact composition of the market portfolio is known and ascertained in tests of its validity.

As pointed out earlier, the book is divided into five chapters. Chapter one is introductory and discusses such issues as the background to the study, the statement of the problem, the objectives of the study, the research hypotheses as well as the significance of the study and its limitations and scope. 
In chapter two, the author presents a comprehensive and in-depth review of the related literature surrounding portfolio theory and the CAPM as well as the recent extensions of the CAPM. This the author did to put the study in proper perspective. Chapter three contains the research methodology adopted as well as the theoretical framework of the study. The chapter also presents a detailed discussion of the data gathering techniques adopted to obtain various data used in the study from such sources as the Nigerian Stock Exchange (NSE), The Securities and Exchange Commission (SEC) and The Central Bank of Nigeria $(\mathrm{CBN})$.

Chapter four contains the detailed analysis of the data gathered using both regression analysis and the test of differences of means. This chapter also presents the report of the empirical findings of the study. The methodology adopted in testing the null hypotheses formulated for this study followed the Sharpe-Cooper single-index market model which was applied to a sample consisting of 70 randomly selected assets listed on the NSE between 2002 and 2005. In all, a total of 144 single-index market model regression equations were estimated by the author using both time-series and cross-sectional data.

By comparing the market parameters generated using the NSE All-Share index with the market parameters generated using the All-Asset market portfolio constructed by the author using ALL the assets listed on the NSE, and employing the test of differences of means statistical technique, the author found, among other findings, that the market parameters generated using the All-Asset market portfolio were significantly different from those generated using the NSE All-Share index. And this is the crux of Dr. Ogbulu's proposition. Given these different market parameters, the expected rates of return would also not be the same but would lead to conflicting results for the same sample of securities.

Overall, the book is a must-read for all experts and professionals in Portfolio theory and Investment analysis. The book is highly illuminating and is capable of opening new vistas in our understanding of the CAPM as well as charting a new path in the quest for conducting tests of its empirical validity in the market place.

The book is highly recommended for scholars and practitioners in finance, Portfolio and security analysis as well as for Investment and Portfolio managers. 